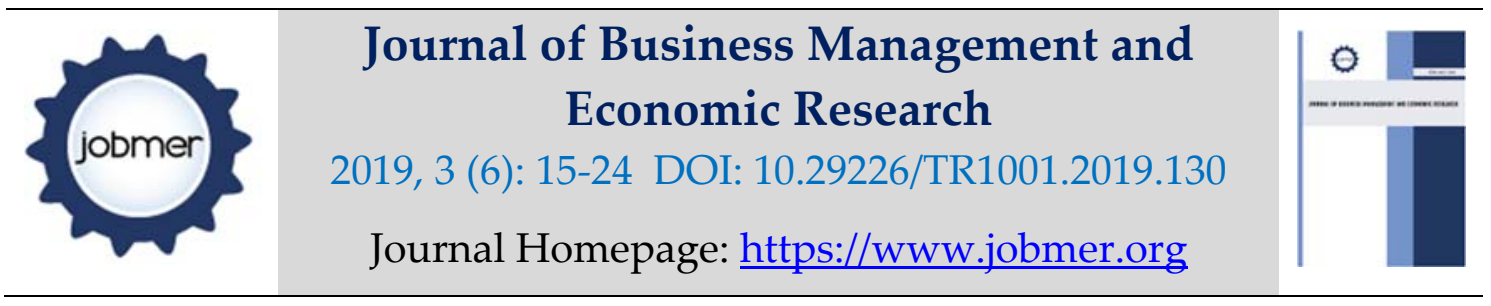

\title{
Added Value of Plants Combination: Paraserianthes Falcatria and Oriza Sativa at the Community Forest in Kapuas District, Indonesia
}

\section{Wahyudi}

Faculty of Agriculture, University of Palangka Raya

wahyudi888@for.upr.ac.id

\begin{abstract}
This research was aimed to compare the plant combination of Paraserianthes falcataria and Oriza sativa and monocultural plantation of Paraserianthes falcataria in order to increase land productivity in Kapuas District. This research consisted of two treatments and each treatment consisted of 17 plots. Data were analysed using homogenity test and analysis of variance using SPSS 20.0. Research was conducted in the community forest project areas in Kapuas District, Central Kalimantan Province in 2017 to 2018. The result showed that at the first year, growth of $\mathrm{dbh}$ and height of Paraserianthes falcataria in plants combination system were $5.44 \mathrm{~cm}$ and $5.25 \mathrm{~m}$ respectively, whereas monocultural system were just $3.79 \mathrm{~cm}$ and $3.53 \mathrm{~m}$ respectively. Plants combination system also produced rice namely 3.05 ton ha-1 in the first year. Thereby, the plants combination of Paraserianthes falcataria and Oriza sativa is better than monocultural plantation of Paraserianthes falcataria. This is the best system to increasing land productivity thereby it was give more added value for increasing income and prosperity of local peoples at Kapuas District, Central Kalimantan.
\end{abstract}

Keywords: Added value, Oriza sativa, Paraserinthes falcatria, plants combination. 


\section{Introduction}

Borneo or Kalimantan island is the second largest island in the Indonesia archipelago. ${ }^{1,2,3}$ Kapuas District is one some regions located in Borneo, Indonesia that has experienced degraded forest caused illegal logging,wild forest fire etc. Plantaion is one of Indonesia's Government Programs that is aimed in increasing degraded forest lands. Based on regulation of Indonesia Ministry of Forestry No.10.1/Kpts-II/2000 and regulation of Indonesia Goverment No.34/2002, forest plantation is directed in degraded forest areas such as shrubs, underbrush, grassland, and other critical land including poor timber potential caused by illegal logging. The development of Industrial Forest Plantation (IFP) has been started in 1980s, especially in Kalimantan and Sumatra. Unhappily, until 2000s the attainment of IFPvis less than 30\%.5 Since year 2007, Indonesia Ministry of Forestry has launched the Community Forest Program duo to increase land productivit and also to create added value through local peoples.2,6,7

Adverse result of Industrial Forest Plantation in Indonesia is caused by the adverse edaphic factor, $, 10,11$ less appropriate of silvicultural technique and technology $y^{8,12}$ and the socio-cultural factor. ${ }^{13}$ The adverse soil is caused by the marginal soil of podzolic red-yellow (ultisol) ${ }^{14}$ and also acidic characteristic with high content of $\mathrm{Fe}$ and $\mathrm{Al}$ caused the binding of Phospor in the ground. ${ }^{12,14}$ Poor knowledge of silvicultural technique, heavy degradation, and poor forest management have caused poor growth of planted forest for some years. ${ }^{11,15,16}$ The lack of local society involvement in plantation forest activity often become serious problem, especially on the forest fire, illegal logging and land occupation.,37,18 Some species which are recommended for forest plantation are Paraserianthes falcataria, Dyera lowii, Hevea brasiliensis, Shorea balangeran, Paraserianthes falcataria, Swietenia mahagony, Eucalyptus spp, Peronema canescens, Gmelina arborea, and others. ${ }^{4}$

Forestry development policy in Indonesia should have been directed to the integrated forest management, including plantation forest development using plants combination system involving local community. ${ }^{1,15}$ Plants combination system is able to be optimal for farming, ${ }^{8}$ creating better nutrient cycle, ${ }^{12,19}$ enhance biodiversity ${ }^{19}$ and also improve growth and yield. ${ }^{20}$

Monocultural system had been applied in Industrial Forest Plantation and also Community forest since some years ago. Some forest concessionaries have applied the plants combination system as part of their plantation system, like Gunung Meranti, Daya Sakti 6, meanwhile community forest that succesfully applied the plants combination system, called agroforestry, located at the 
Lawang Tamang, Tumbang Tihis, Manyarung etc. that is administratively located in Kapuas District, Central Kalimantan, Indonesia.

The community at the Kapuas District has developed the plants combination system on their farm. This effort is able to increase added value in the form of minimizing the use of inorganic manure, minimizing of tending activity, improving growth and yield of plantation and also to create positive impact at local peoples in the form of improved production, better perception and also create care for natural resources and environment.

\subsection{The Objectives of Research}

The aim of this research was to analyze added value of agroforestry system, i.e. combination of Paraserianthes falcatria and Oriza sativa at the community forest in Kapuas District, Indonesia

\section{Method}

\subsection{Research Site and Date}

This research was conducted in the community forest at Lawang Tamang, Kapuas District, Central Kalimantan Province. Climate type of A (Schmidt and Ferguson, 1951) with precipitation of $2.650 \mathrm{~mm}$ year-1. Initially vegetation was underbrush and grassland (Imperata cylindrica). Other species were Macaranga macroptera, M. triloba, M. grandifolia, M. peltata, Melastoma malabathricum, Vitex sp, Hyptis capitata, Cyperus spp., etc. Soil type was ultisol and soil texture was sandy clay. Research has been done at November 2017 to December 2018.

\subsection{Research Procedures}

Land clearing was done by disc plow. The soil was treated with Calcium $\left(\mathrm{CaCO}_{3}\right) 500 \mathrm{~kg} \mathrm{ha}^{-1}$, at one week before plantation. Paraserianthes falcataria seedling was planted in October 2018 with spacing of $2.5 \mathrm{~m} \times 2.5 \mathrm{~m}$. All seedling of Paraserianthes falcaria were come from the nursery with uniform treatment.

Plot establishment. Plot 1 (as treatment 1 ) was plants combination system, i.e. the mixing of Paraserinthes falcataria and mount-paddy (Oriza sativa) with continued manuring, and plot 2 (as treatment 2) was intensive monocultural system (Paraserianthes falcataria plantation with continued manuring). Each treatment consisted of 17 plots as replication meanwhile size of each plot was $15 \mathrm{~m}$ x $10 \mathrm{~m}\left(=150 \mathrm{~m}^{2}\right)$ which was randomly placed. 
Continued manuring was used the composition of anorganic manure i.e. Urea mixed $\mathrm{KCl}$ namely $250 \mathrm{~kg} \mathrm{ha}^{-1}$. At the 2 to 3 weeks after Paraserianthes falcataria being planted, mount-paddy (Oriza sativa) was planted in plot 1 (t1) with dibble (that is wooden tool with a sharp end for making holes in the ground). Planting holes spacing was $25 \mathrm{~cm} \times 25 \mathrm{~cm}$ and each hole was filled with 2 to 4 seeds of mount-paddy and then covered by topsoil.

Replanting seedling of Paraserianthes falcataria (replacement of dead seedling with a new one) was conducted on $2^{\text {rd }}$ month after planting of trees. Data of diameter at breast height $(\mathrm{dbh})$ and height of Paraserianthes falcataria at 1 year after planting were collected Harvested mount-paddy (Oriza sativa) were done at 4.5 months after planting then result of paddy yield was recorded.

\subsection{Data Analysis}

Data were analyzed using analyse of varians (Anova) and LSD test, using SPSS 20.0.

\section{Result and Discussion}

\subsection{Growth of Paraserianthes falcataria}

Growth of diameter at breast height (dbh) and height of Paraserianthes falcataria in plants combination system (t1) and monoculte plantation system were showed at Table 1. The data indicated that in the first year, plants combination system showed the best growth with mean of $\mathrm{dbh}$ and height were $3.88 \mathrm{~cm}$ and $4.12 \mathrm{~m}$ respectively, meanwhile monoculture plantation showed lower growth namely $2.54 \mathrm{~cm}$ and $2.31 \mathrm{~m}$ respectively.

Table 1. Mean of $\mathrm{dbh}$ and height of Paraserianthes falcataria in the 2 treatments

\begin{tabular}{ccccc}
\hline $\begin{array}{c}\text { No. } \\
\text { Plot }\end{array}$ & $\begin{array}{c}\text { Mean of dbh }(\mathbf{c m}) \\
\mathrm{t} 1\end{array}$ & $\begin{array}{c}\text { Mean of height }(\mathbf{m}) \\
\mathrm{t} 1\end{array}$ & $\mathrm{t} 2$ \\
\hline 1 & 6.12 & 4.23 & 5.88 & 3.94 \\
2 & 5.32 & 4.22 & 5.21 & 4.11 \\
3 & 4.67 & 3.56 & 5.01 & 3.54 \\
4 & 4.56 & 4.22 & 4.89 & 3.95 \\
5 & 5.32 & 4.33 & 4.97 & 4.11 \\
6 & 6.34 & 3.54 & 5.45 & 2.95 \\
7 & 5.01 & 3.45 & 4.87 & 2.85 \\
8 & 5.43 & 2.99 & 5.01 & 3.11 \\
9 & 6.21 & 3.23 & 5.78 & 3.04 \\
10 & 6.34 & 3.56 & 6.12 & 3.22 \\
11 & 5.32 & 4.12 & 5.55 & 3.65 \\
12 & 5.21 & 4.23 & 5.12 & 3.95 \\
13 & 4.88 & 3.67 & 4.76 & 3.25 \\
14 & 5.32 & 3.45 & 4.95 & 3.22 \\
15 & 5.32 & 3.56 & 4.85 & 3.55 \\
16 & 6.11 & 3.88 & 5.99 & 3.67 \\
17 & 5.04 & 4.23 & 4.88 & 3.95 \\
\hline Average & 5.44 & 3.79 & 5.25 & 3.53 \\
\hline
\end{tabular}


Notes $=$ t1: plants combination system (Paraserianthes falcataria mix Oriza sativa), t2: monoculte plantation of Paraserianthes falcataria.

Based on the homogeneity test, the data of $\mathrm{dbh}$ and height of Paraserianthes falcataria were the significant value each equal to 0.31 and 0.79 respectively which were bigger than 0.05 so that all data were homogeneous and the next analysis can be done. Based on analyse of variationin of $\mathrm{dbh}$ and height growth of Paraserianthes falcataria, they showed that significant value namely 0.00 $<0.05$, so there were significant different between the treatments. Thereby, dbh and also height growth of Paraserianthes falcataria in the plants combination system (t1) was better than the monocultural system (t2). Picture 1 showed a dbh growth and height growth of Paraserianthes falcataria.

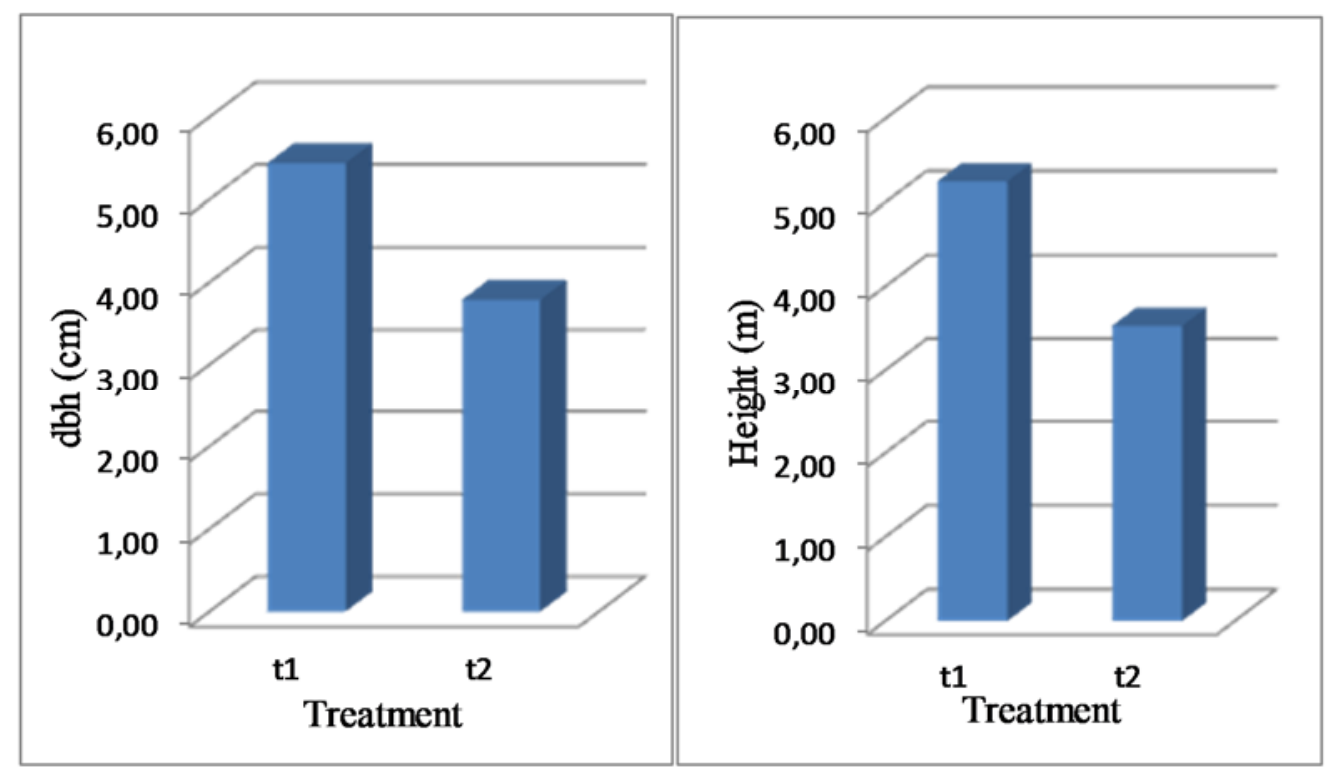

Figure 1. Comparison of dbh and height growth of Paraserianthes falcatariain

The data showed that there is positive correlation between $\mathrm{dbh}$ and heightly growth of Paraserianthes falcataria and both represent important parameters in tree growth ${ }^{21}$ and also as an indicator that Paraserianthes falcataria plant grow normally. ${ }^{22}$ The tree growth quality was represented by function of density which could be arranged through their spacing. ${ }^{23,24}$ The good wood quality was yielded from well-balanced and good tree growth since initial stage ${ }^{22,25}$ The 2.5 $\mathrm{m} \times 2.5 \mathrm{~m}$ spacing at Paraserianthes falcataria plantation could result a good influence on the architecture of Paraserianthes falcataria because it produces well-balance effect of phototrophism. 
Plants combination system was the best system for the growth of dbh and height of Paraserianthes falcataria plantation (Table 1). This plant is a fast growing species that needs the availability of nutrient to balance its growth rate. ${ }^{24,26}$ Plantation area includes critical land and degradation land (regulation of Indonesia Goverment No.34/2002) and it has some limited factors ${ }^{7}$ that was marginal land, podzolic red-yellow soil, $\mathrm{pH} 4$ to 5.5 - that has the character of acid soil was high of $\mathrm{Fe}$ and $\mathrm{Al}, 11,14,27$ but by giving base manure of calcium cloride (CaCO3) equals to $750 \mathrm{~kg} \mathrm{ha}^{-1}$ and also continuous manuring with fertilizer of urea: $250 \mathrm{~kg} \mathrm{ha}^{-1}$ and $\mathrm{KCl}: 250 \mathrm{~kg} \mathrm{ha}^{-1}$ could yield better growth of Paraserianthes falcataria.Fisher and Binkley expressed that growth of plant was influenced by soil tilage, site and species. ${ }^{12}$ Soil tilage with plow could also give positive affect to mixed mineral soil above and underground. Waste and other organik substance arethe sources of soil nutrient therefore need to be retained. The marginal land has low potency for cultivation but with the technological treatment and correct processing system could become productive land. ${ }^{10}$ The use of basic manure and continued manuring isrecommended and also suggested to promote growth on marginal farm. 10,12,23,24

\subsection{Plants combination System}

Plots of plants combination system (t1) produced average yield of mount-paddy (Oriza sativa) of 3.05 ton $\mathrm{h}^{-1}$ in the first year. This paddy yield was better than the result of mount-paddy from local people using shifting cultivation that less environmental friendly which is just 0,5 to 1,3 ton ha $^{-1} .^{16}$ The Paraserianthes falcataria canopy was wide and big which progressively caused decreasing of light intensity which was distributed on the forest floor ${ }^{23}$ and could reduce photosynthetic quality and quantity and also decreased the paddy productivity. .28 


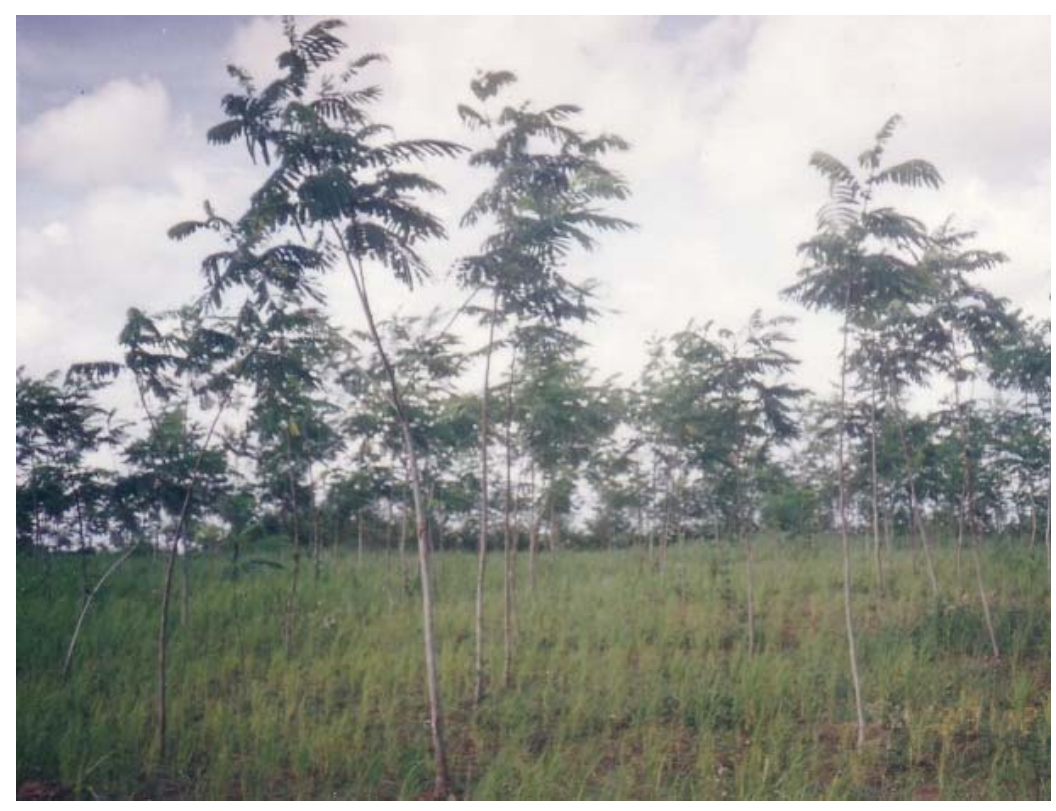

Picture 1. Paraserianthes falcataria mixed Oriza sativa in research plots of Kapuas District

Pursuant to this research result, the growth of Paraserianthes falcataria on the plants combination system is better than monoculture system. Based on evaluation of social aspect, economic and culture, the plants combination system was the best method compared to themonocultural system because they are able to employ morelabour and to improve income of local peoples, creating cooperation among local peoples and management unit that could contribute to sustainability natural resources ${ }^{1}$ and also could improve the positive perception to the forest development and plants combination system in the forest region.

The other uses on the plants combination system was security aspect to keep from forest fire. A lot of study expressed that most caused of forest fire was human factor. ${ }^{17,18,29}$ The local peoples tradition, especially on the surrounding forest region, was opening the farm by combustion and it was causing forest fire. ${ }^{17,29}$ Plants combination system could reduce the number of forest fire because the local community couldtake care of their plant.

Plants combination system is believed to be able to depress the number of forest damage, because the local people in the settled cultivation are more productive with intensification pattern. The involvement of local peoples to manage natural resources using participatory rural appraisal (PRA) concept that had been adopted by some management unit in Indonesia. With this concept, the local peoples had a share to make the planning, managing, controlling and benefiting of natural resources in the surrounding habitation with sustained principal. ${ }^{28}$ Plants combination 
system is the better solution to increase land productivity, thereby, it was give more added value for increasing income and prosperity of local peoples.

Constraint of plants combination system for wider scale is land accessibility and continued activity. Generally, the society prefers to establish plants combination activity on the land that nearby their habitation. They couldn't use the same location after two or three times of planting period so they have to look for a new farm afterward. The good planning in the plants combination management could create continued activity.

\section{Conclusion}

Plants combination between Paraserianthes falcataria and Oriza sativa give the better $\mathrm{dbh}$ and height growth of Paraserianthes falcataria, namely $5.44 \mathrm{~cm}_{\text {year }}{ }^{-1}$ and $5.25 \mathrm{~m}_{\text {year-1 }}$ respectively, and $^{-}$ also mount-paddy (Oriza sativa) yield, namely 3.05 tonnes ha-1. c This is the best system to increasing land productivity thereby it was give more added value for increasing income and prosperity of local peoples at Kapuas District, Central Kalimantan.

\section{Acknowledgements}

The author thank for Juwadi and Ir. Winadari for use plots of Paraserianthes falcataria and paddy (Oriza sativa) and also for our friends in PT Gunung Meranti, Kapuas District, Central Kalimantan, Indoensia.

\section{References}

[1] Wahyudi and Ogbinar A. 2011. Technique and EconomicsCycles of Paraserianthes falcataria Plantation in Kapuas District, Central Kalimantan. Journal of Tropical Forest Vol.6 No.2 2011. Pg.9-20.

[2] Wahyudi. 2012. Indonesian Tropical Forest, Biodiversity Conservation and Ecotourism Development. In the Proceeding of the International German Alumni Summer School of Biodiversity Management and Tourism Development. Cuvillier Verlag Goettingen, Germany. 
[3] Suratmo FG, EA Husaeni, N Surati J. 2003. Basic Science of Forest Fire. Faculty of Forestry, Bogor Agricultural University, Bogor.

[4] Ministry of Forestry and Estate, 1998. Hand Book of Forestry in Indonesia. Forest Research and Development Agency. Ministry of Forestry and Estate, Republic of Indonesia, Jakarta.

[5] Ministry of Forestry and Estate, 2000. Management of Critical Land in the Forest Region. Ministry of Forestry and Estate, Republic of Indonesia, Jakarta.

[6] Ministry of Forestry, 2007. Community Plantation Forest Development. Background, Fact, and Policy. Ministry of Forestry, Republic of Indonesia, Jakarta.

[7] Ministry of Forestry, 2010. Intensified Silvicultural System in the Management Unit Models, Concept and Implementation. General Director of Forest Utility,Ministry of Forestry, Republic of Indonesia, Jakarta.

[8] Wahjono J. 2010. The Plants Combination Technique. Forest Research and Development Agency, Bogor.

[9] Ministry of Agriculture, 2003. Technical Guideline of Land Evaluation for Agricultural Commodity. Agricultural Research and Development Agency, Ministry of Agriculture, Republic of Indonesia, Bogor.

[10] Noor, M. 1996. Paddy in the Marginal Land. PT. Penebar Swadaya, Jakarta.

[11] Sutedjo MM, AG Kartasapoetra. 1991. Introduction of Soil Science. Penerbit Rineka Cipta, Jakarta.

[12] Fisher RF, Dan Binkley. 2000. Ecology and Management of Forest Soil. Third Edition. John Wiley \& Sons, Inc., New York.

[13] Ministry of Agriculture, 2008. Agricultural Revitalization for Food Security. Ministry of Agriculture, Republic of Indonesia, Jakarta.

[14] McKinnon K, G Hatta, Hakimah H, Arthur M. 2000. Ecologi of Kalimantan. Canadian International Development Agency. Prenhallindo, Jakarta.

[15] De Foresta H, A Kusworo, G Michon, WA Djatmiko. 2000. Plants combination in Indonesia. ICRAF Southeast Asia. SMT Grafika Desa Putera, Jakarta. 
[16] Soeseno OHandNa'iem M. 1995. Industrial Forest Plantation, the Problems and Its Solutions. General Director of Forest Utility, Jakarta.

[17] Suyatno. 2004. Forest Fire, Problems and Its Solution. Center for International Forest Research (CIFOR), Bogor.

[18] Wibowo, A. 2003. Forest Fire Prevention in Indonesia. Forest Research and Development Agency, Bogor.

[19] Kosasih, A.S., Rina B., Budi R. 2006. The Silviculture of Mixed Forest Plantation. Forda, Ministry of Forestry, Republic of Indonesia, Bogor.

[20] Sabarnurdin, S. 2008. Plants combination. Strategyfor Land Utility to Sustainability Development. Faculty of Forestry, Gadjah Mada University, Yogyakarta.

[21] Kozlowski TT, Pallardy SG. 1997. Physiology of Woody Plants. Academic Press.

[22] Barnett, J.R. and G. Jeronimidi. 2003. Wood Quality and Its Biological Basis. Blackwell Publishing CRC Press.

[23] Manan, S. 1995. Why Using Mixed Forest Plantation?Paper on Landscaping Seminar. General Director of Forest Utility, Ministry of Forestry, Republic of Indonesia, Jakarta

[24] Yulianti B. And Wahyudi.2012. Plantation Technique ofParaserianthes falcataria. Forda, Ministry of Forestry, Republic of Indonesia, Jakarta.

[25] Haygreen JG and LB Jim. 1982. Forest Product and Wood Science. The Iowa State University Press.

[26] Akbar A, Rusmana, Panjaitan S. 2012. Cultivation, Utilization, and Prospect of Paraserianthes falcataria. Forest Research Agency, Banjarbaru.

[27] Siswomartono, D. 1989. Encyclopedia of Natural ResourcesConservation. Penerbit Erlangga, Jakarta.

[28] Gardner, F.P., R. Brent P., Roger L.M. 1991. Physiology of Crop Plant. The Iowa State University Press.

[29] Sagala, A.P.S., 1988. Controling Forest Fire in the Reforestation Land in Tapin. Banjarbaru Reforestation Technique.

[30] Singh, P., P.S. Pathak, M.M.Roy. 1995. Plants combination Sistem for Sustainable Land Use. Science Publishers, Inc. 